\title{
IDENTIFIKASI JAMUR ENDOFIT DAUN JARUM Pinus radiata MENGGUNAKAN METODE EKTRAKSI DNA SECARA LANGSUNG
}

Identification of endophyte fungi of Pinus radiata needles using direct DNA extraction methods

\author{
Istiana Prihatini \\ Balai Besar Penelitian Bioteknologi dan Pemuliaan Tanaman Hutan \\ Jl. Palagan Tentara Pelajar Km 15, Purwobinangun, Pakem, Sleman, Yogyakarta 55582 \\ E-mail: istiana.prihatini@biotifor.or.id
}

\begin{abstract}
Pinus radiata is the major softwood species planted in New Zealand and Australia. Endophyte fungi that have been extensively studied in conifers needles mainly based on fungal isolation and also rarely conducted in Pinus radiata. This study aimed to observe the optimum condition of P. radiata needles sample for direct extraction of fungal DNA and to identify the fungi associated with $\mathrm{P}$. radiata needles in Plenty plantations by a direct PCR approach. Room temperature dried needles produced clear and consistent DNA amplification compare to fresh needles, and needles dried on drying room or drying machine. Capnodiales was the most diverse group and no fungal pathogen detected in this study. DNA sequence data from direct DNA extraction of $\mathrm{P}$. radiata needles provided sufficient discrimination and identification of fungal species.
\end{abstract}

Key words: Pinus radiata, endophyte fungi, direct DNA extraction, fungal identification

\begin{abstract}
ABSTRAK
Pinus radiata merupakan jenis pohon berkayu lunak yang banyak ditanam di Selandia Baru dan Australia. Jamur endofit telah banyak dipelajari pada daun jarum beberapa jenis konifer melalui teknik isolasi jamur namun belum banyak dilakukan pada jenis Pinus radiata. Penelitian ini dilakukan untuk mengetahui kondisi daun jarum $P$. radiata yang optimal bagi proses ektraksi DNA jamur endofit serta mengetahui jenis-jenis jamur endofit yang berasosiasi dengan daun jarum $P$. radiata di hutan tanaman Plenty melalui metode PCR secara langsung. Daun jarum yang telah dikeringkan pada suhu ruangan memberikan hasil amplifikasi DNA yang lebih jelas dan konsisten dibandingkan dengan daun yang masih segar serta daun yang telah dikeringkan pada ruang pengering maupun pada alat pengering. Pada penelitian ini, Cap-nodiales merupakan kelompok jamur yang paling banyak dijumpai serta tidak ditemukan jenis jamur patogen. Data sekuen DNA yang diperoleh melalui ektraksi DNA secara langsung dari daun jarum $P$. radiata mampu memberikan perbedaan serta identifikasi bagi jenis-jenis jamur.
\end{abstract}

Kata kunci: Pinus radiata, jamur endofit, ekstraksi DNA secara langsung, identifikasi jamur 


\section{PENDAHULUAN}

Pinus radiata merupakan jenis tanaman kayu lunak yang merupakan komoditas penting di beberapa negara terutama di belahan bumi bagian selatan. Jenis ini merupakan jenis eksotis yang ditanam secara luas misalnya di Selandia Baru, Chili, Australia, Afrika Selatan dan Argentina dengan total luasan hutan tanaman di seluruh dunia mencapai 4 juta ha (Mead, 2013). Di Selandia Baru, P. radiata merupakan jenis utama yang dikembangkan pada hutan tanaman dengan luasan mencapai 90\% dari total hutan tanaman (NZFOA, 2012), sedangkan di Australia luasannya meliputi $42,7 \%$ dari total hutan tanaman (ABARES, 2012).

Hutan tanaman $P$. radiata di beberapa bagian dunia saat ini sedang mengalami banyak serangan hama dan penyakit. Hama yang menyerang secara luas antara lain adalah Sirex noctilio yang dilaporkan di Australia (Collett and Elms, 2009) dan Amerika Serikat (USDAFS, 1993), kumbang Ips grandicollis dan Hylastes ater di Selandia Baru (Watson et al., 2008), serta Essigella californica di Australia (May, 2004) dan Selandia Baru (Watson et al., 2008). Jamur patogen yang menyerang $P$. radiata secara luas adalah Dothistroma septosporum,
Sphaeropsis sapinea (Mead, 2013) dan Fusarium circinatum (Ganley et al., 2011). Adapun patogen yang menyerang hanya pada wilayah tertentu misalnya Neonectria fuckeliana di Selandia Baru (Ramsfield et al., 2013), Phytopthora ramorum dan Cyclaneusma minus di Australia dan Selandia Baru (Mead, 2013), sedangkan di Tasmania ditemukan penyakit spring needle cast (SNC) yang belum diketahui penyebabnya (Podger and Wardlaw, 1990).

Dampak yang ditimbulkan oleh beberapa hama dan penyakit tersebut sangat signifikan secara ekonomis, misalnya hama E. californica di Australia mengurangi keuntungan sebesar kurang lebih AUD 21 juta per tahun (May, 2004), sedang penyakit Cyclaneusma minus di Selandia Baru menyebabkan kerugian sebesar NZD 38 juta per tahun (Watt et al., 2011). Untuk itu diperlukan upaya untuk mengendalikan serangan hama dan penyakit secara efektif. Salah satunya adalah dengan melakukan identifikasi jenis organisme penyebab penyakit sebelum dampak serangan mulai terlihat. Jamur patogen umumnya dapat bersifat laten di dalam tubuh tanaman inang sebelum menimbulkan gejala penyakit (Moricca and Ragazzi, 2007) . 
Penelitian ini dilakukan untuk mengetahui kondisi daun jarum $P$. radiata yang optimal pada proses ektraksi DNA jamur endofit secara langsung dari daun jarum $P$. radiata serta untuk mengetahui jenis-jenis jamur yang berasosiasi dengan daun jarum $P$. radiata di hutan tanaman Plenty melalui metode PCR secara langsung.

\section{BAHAN DAN METODE}

\section{A. Bahan penelitian}

Penelitian ini menggunakan daun jarum $P$. radiata yang dikoleksi secara acak dari hutan tanaman yang berumur 4 tahun di daerah Plenty Tasmania. Satu cabang daun dipilih secara acak untuk dipergunakan dalam beberapa perlakuan yang berbeda yaitu:

1. disimpan pada suhu ruang $\left(30^{\circ} \mathrm{C}\right)$ selama 24 jam dan 96 jam

2. dikeringkan pada mesin pengering $\left(45^{\circ} \mathrm{C}\right)$ selama 24 jam

3. dikeringkan pada ruangan pengering (suhu $38^{\circ} \mathrm{C}$ ) selama 24 jam dan 72 jam

4. material segar yang disimpan secara langsung pada suhu $\left(-80^{\circ} \mathrm{C}\right)$.

Pada setiap perlakuan digunakan sebanyak tiga tangkai daun (berisi 3 helai daun jarum).

\section{B. Metode Penelitian}

\section{Ekstraksi DNA}

Semua sampel daun jarum yang sudah disimpan dalam kondisi yang berbeda kemudian dipotong menjadi ukuran $0,5 \mathrm{~cm}$ dan digerus menggunakan mortar dan alat pengerus porselin dengan bantuan nitrogen cair. Ekstraksi DNA dilakukan menggunakan buffer SDS (Raeder and Broda, 1985) sesuai protokol yang digunakan pada Glen et al. (2002).

\section{Amplifikasi PCR}

Reaksi PCR dilakukan menggunakan Mangotaq (Bioline) dengan konsentrasi akhir: $67 \mathrm{mM}$ Tris-HCl, $\mathrm{pH} 8,8 ; 16 \mathrm{mM}$ $\left(\mathrm{NH}_{4}\right)_{2} \mathrm{SO}_{4}$ (pada $5 \mathrm{x}$ reaction buffer yang disediakan oleh Bioline); 2,0 mM magnesium chloride (Promega); $200 \mu \mathrm{M}$ deoxynucleotide triphosphate (Bioline); 0,25 $\mu \mathrm{M}$ oligonucleotide primer (Geneworks); 0,25 unit Biotaq DNA polymerase (Bioline); $10 \mathrm{mg} / \mathrm{ml}$ of bovine serum albumin (Fisher Biotec); $10 \mu 1$ DNA yang sudah diencerkan 20x menggunakan TE sebagai template DNA dan ditambahkan air steril (Astra Zeneca) hingga volume akhir mencapai 50 $\mu 1$. Primer yang digunakan pada penelitian ini adalah primer ITS4A (Larena et al., 1999) dan ITS5 (White et al., 1990). 
Amplifikasi PCR dilakukan pada mesin Peltier Thermal Cycler PTC-225 (MJ Research) dengan pemanasan awal pada suhu $95^{\circ} \mathrm{C}$ selama 3 menit dan amplifikasi sebanyak 35 siklus yang terdiri dari proses denaturasi pada suhu $94^{\circ} \mathrm{C}$ selama 30 detik, proses annealing pada suhu $55^{\circ} \mathrm{C}$ selama 30 detik dan pemanjangan (extention) pada suhu $72^{\circ} \mathrm{C}$ selama 2 menit dan pemanjangan akhir (final extention) selama 7 menit pada suhu $72^{\circ} \mathrm{C}$.

\section{Elektroforesis}

Produk hasil amplifikasi PCR dipisahkan melalui proses elektroforesis pada gel agarose 1\% (Fisher Biotech) pada 10 volts/cm selama 30 menit menggunakan MI-DEAR 120 High Performance Gel System (Biokeystone). Gel agarose kemudian divisualisasi pada transilluminator (Vilber Lourmat) setelah dilakukan staining menggunakan Ethidium Bromide 0,5ug/ ml (MOBIO-Geneworks) selama 20 menit dan gambar diambil menggunakan kamera (Vilber Lourmat) yang terhubung dengan transilluminator.

\section{Kloning DNA}

Kloning terhadap DNA hasil PCR dilakukan untuk memisahkan DNA setiap individu jamur yang berbeda yang tercampur di dalam sampel daun yang sama. Proses kloning dilakukan menggunakan GEMâ-T Easy Vector (Promega). Hasil amplifikasi dari proses PCR dipurifikasi terlebih dahulu menggunakan UltraCleanä PCR Clean-up Kit (MO BIO) sesuai dengan protocol yang disediakan oleh perusahaan serta dipresipitasi dengan menambahkan $5 \mathrm{M} \mathrm{NaCl}$ dan $100 \mu$ l ethanol 100\%. DNA kemudian digunakan pada proses ligasi. Reaksi ligasi dilakukan pada hari yang sama dengan PCR dan purifikasi DNA, mengikuti prosedur yang disediakan oleh perusahaan. Reaksi ligasi disimpan pada suhu $5^{\circ} \mathrm{C}$ selama sekitar 24 jam sebelum dilakukan proses transformasi. Setelah proses transformasi pada sel kompeten JM109 (Promega) sesuai dengan protocol yang disediakan oleh perusahaan, sebanyak $100 \mu \mathrm{l}$ hasil reaksi transformasi kemudian ditumbuhkan pada media agar LB padat dengan penambahan Ampicillin, IPTG dan X-gal serta diinkubasi pada suhu $37^{\circ} \mathrm{C}$ semalam. Koloni sel bakteri hasil transformasi yang memiliki plasmid dengan sisipan DNA (berwarna putih) diambil menggunakan tusuk gigi steril dan disuspensikan dalam $50 \mu 1$ TE. Suspensi sel bakteri dalam TE ini kemudian digunakan 
secara langsung dalam proses PCR tahap kedua dengan prosedur yang sama dengan PCR pertama (bagian II.B.2) menggunakan primer ITS1 dan ITS4 (White et al., 1990).

\section{DNA Sequencing}

Hasil amplifikasi dari reaksi PCR tersebut kemudian dikirim ke Macrogen Ltd (Seoul, Korea) untuk dilakukan sekuensing mengunakan primer ITS1 (White et al. 1990).

\section{Analisis data hasil sequencing}

Gambar kromatogram hasil sekuensing yang diperoleh dari website Macrogen (http://dna.macrogen.com/eng/) dianalisa dan jika diperlukan dilakukan pengeditan menggunakan program ChromasPro version 1.34 yang dapat diunduh secara gratis (http:// www.technelysium.com.au/ChromasPro. html). Sekuense DNA jamur kemudian dicocokkan dengan sekuen jamur yang tersedia pada database nukleotida National Center for Biotechnology Information (NCBI) menggunakan program BLAST (Basic Local Alignment Search Tool) yang dikembangkan oleh Altschul et al., (1997). Hasil pencocokan identitas jamur tersebut kemudian dikelompokkan sesuai dengan tingkat kemiripannya kemudian setiap kelompok analisis menggunakan program ClustalW (Thompson et al., 1994). Setiap polimorfisme yang teramati pada setiap kelompok sebelumnya dicek ulang terlebih dahulu pada gambar kromatogram untuk melihat adanya hasil pembacaan basa yang salah. Identitas jenis jamur serta Operational taxonomic units (OTUs) ditentukan berdasarkan tingkat kemiripan sekuen dengan jenis jamur yang sudah dikenal yang tersedia pada database melalui analisis filogenetik menggunakan pendekatan maximum likelihood dengan program DNAML yang tersedia pada paket program PHYLIP (Felsenstein, 1989). Gambar pohon filogenetik dibuat menggunakan program TreeView (Page, 1996) dan diedit menggunakan program Mega4 (Tamura et al., 2007).

\section{HASIL DAN PEMBAHASAN}

\section{A. Hasil}

1. Ekstraksi DNA menggunakan 4 kondisi sampel daun yang berbeda

Hasil amplifikasi PCR menunjukkan bahwa sampel daun yang telah dikeringkan (layu) memberikan hasil pita DNA yang lebih jelas dibandingkan dengan sampel 
daun yang masih basah atau segar (Gambar

1). Pengeringan daun yang dilakukan di dalam suhu ruangan memberikan hasil yang lebih konsisten dibandingkan dengan
2 metode pengeringan yang lain. DNA yang didapatkan dengan metode pengeringan dalam suhu ruangan tersebut digunakan dalam kegiatan cloning dan sekuensing.

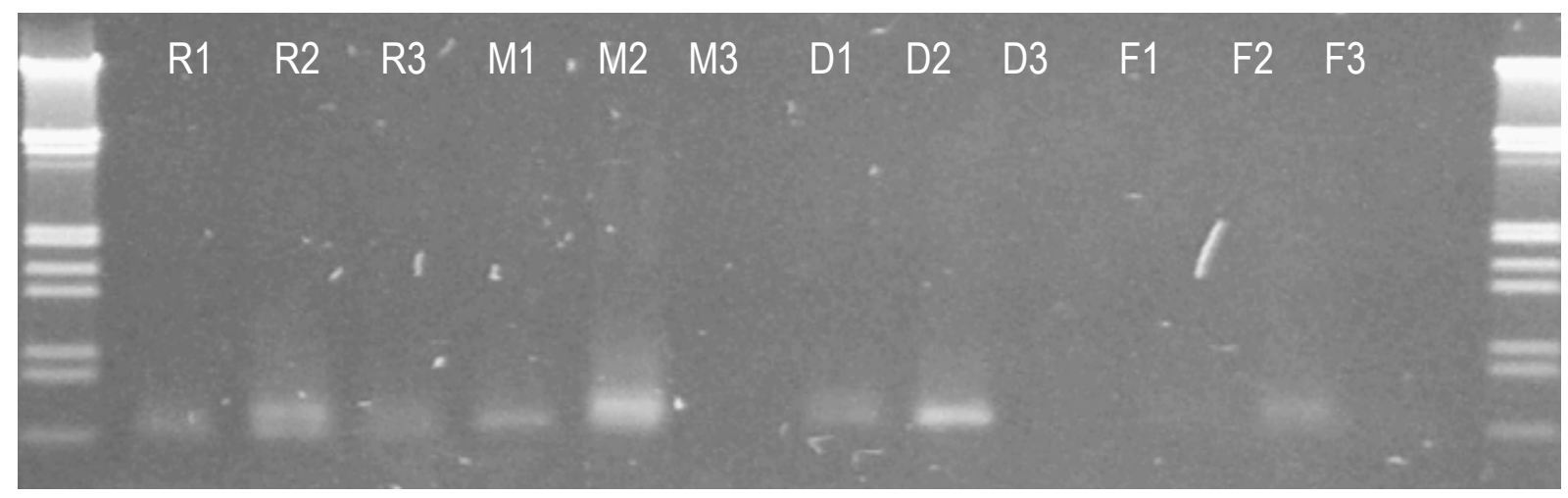

Gambar 1. Gambar 1.Hasil amplifikasi DNA jamur dari daun jarum sehat Pinus radiata dari beberapa daun yang berbeda serta metode penyimpanan yang berbeda; $\mathrm{R}=$ suhu ruang $\left(30^{\circ} \mathrm{C}\right) ; \mathrm{M}=$ mesin pengering $\left(45^{\circ} \mathrm{C}\right) ; \mathrm{D}=$ ruang pengering $\left(38^{\circ} \mathrm{C}\right)$ dan $\mathrm{F}=$ daun basah. Nomor 1,2 dan 3 menunjukkan sampel daun yang berbeda

Hasil amplifikasi PCR dari sampel daun yang telah dikeringkan pada suhu ruangan kemudian digabungkan menjadi satu dan digunakan sebagai sampel pada reaksi cloning dan PCR tahap kedua serta dilakukan sekuensing DNA yang dilanjutkan dengan identifikasi jenis jamur.

2. Sekuensing DNA jamur yang diekstraksi pada daun jarum P. radiata

Dua puluh empat sel bakteri hasil kloning yang dipilih secara acak digunakan dalam proses sekuensing. Hasil analisa sekuensing terhadap DNA jamur yang diekstraksi dari daun jarum Pinus radiata yang telah dikeringkan pada suhu ruangan disajikan pada Tabel 1.
Hanya satu jenis jamur yaitu Penicillium corylophilum yang dapat teridentifikasi melalui sekuen ITS melalui tingkat kemiripan yang tinggi (99\%) dengan sekuen dari database NCBI. Beberapa jenis jamur teridentifikasi dengan kemiripan yang cukup tinggi (98-99\%) terhadap lebih dari satu jenis jamur misalnya Cladosporium, Catenulostroma dan Lophodermium dapat diketahui kemiripan sekuensenya dengan jamur lain hingga tingkat spesiesnya. Beberapa sampel lain memiliki kemiripan yang rendah $(<95 \%)$ terhadap sekuen ITS dari jamur lain pada database. 
Tabel 1. Hasil analisis sekuensing DNA jamur yang diekstraksi secara langsung dari daun P. radiata yang dikoleksi pada hutan tanaman di Plenty Tasmania

\begin{tabular}{|c|c|c|}
\hline Identitas klon & Hasil pencarian menggunakan program BLAST & Familia \\
\hline Plenty 209 & $\begin{array}{l}\text { 98-99\% sesuai dengan beberapa jenis Lophodermium termasuk } \\
\text { L. conigenum no akses pada NCBI FJ861975 dan L. australe CMW } \\
34720 \text { no akses FJ861970. }\end{array}$ & Helotiales \\
\hline Plenty 210 & $\begin{array}{l}\text { 92\% sesuai dengan beberapa jenis Dothidiales termasuk Sphaerulina } \\
\text { eucalypti no akses pada NCBI AY293060, Selenophoma eucalypti } \\
\text { no akses AY293059 dan Sydowia eucalypti CPC14927 no akses } \\
\text { GQ303297 }\end{array}$ & Dothideales \\
\hline Plenty 211, 214 & $\begin{array}{l}99 \% \text { sesuai dengan uncultured Pezizomycotina no akses pada NCBI } \\
\text { FJ554038 dan hanya mendekati } 87 \% \text { sesuai dengan beberapa jenis } \\
\text { Phaeococcomyces termasuk } P \text {. mexicanus strain CPC } 22069 \text { no akses } \\
\text { KJ152783 dan } P \text {. aff. nigricans no akses JX188194 }\end{array}$ & Chaetothyriales \\
\hline Plenty 212 & $\begin{array}{l}\text { 99\% sesuai dengan beberapa jenis Cladosporium, termasuk } \\
\text { C. cladosporioides no akses pada NCBI KF938459, C. macrocarpum } \\
\text { no akses KF } 887140 \text { dan C. iridis no akses KF938460 }\end{array}$ & Capnodiales \\
\hline Plenty 213,215 & $\begin{array}{l}\text { hingga } 95 \% \text { sesuai dengan Rachicladosporium, termasuk } R \text {. pini } \\
\text { CPC16770 no akses pada NCBI JF951145, R. luculiae strain } \\
\text { CPC11407 no akses EU040237 dan } R \text {. americanum CBS124774 no } \\
\text { akses GQ303292 }\end{array}$ & Capnodiales \\
\hline Plenty 216 & $\begin{array}{l}99 \% \text { sesuai dengan uncultured Pezizomycotina no akses pada NCBI } \\
\text { FJ554038 dan hanya mendekati } 87 \% \text { sesuai dengan beberapa jenis } \\
\text { Phaeococcomyces termasuk } P \text {. mexicanus strain CPC } 22069 \text { no akses } \\
\text { KJ152783 dan } P \text {. aff. nigricans no akses JX188194 }\end{array}$ & Chaetothyriales \\
\hline Plenty 301 & $\begin{array}{l}\text { Hingga 94\% sesuai dengan Preussia, termasuk P. tetramera no akses } \\
\text { pada NCBI GQ203792, P. dubia no akses GQ203777 dan Sporormiella } \\
\text { irregularis no akses GQ203780 }\end{array}$ & Pleosporales \\
\hline $\begin{array}{l}\text { Plenty } 302, \\
303,304,305 \\
307,309,310 \\
311,312,316\end{array}$ & $\begin{array}{l}\text { 99\% sesuai dengan Penicillium corylophilum no akses pada NCBI } \\
\text { KF170363, KC692220 dan JQ272469 }\end{array}$ & Eurotiales \\
\hline $\begin{array}{l}\text { Plenty } 306,308, \\
315\end{array}$ & $\begin{array}{l}\text { 95\% sesuai dengan Phaeotheca fissurella CBS } 520.89 \text { no akses } \\
\text { pada NCBI AJ244255 dan hingga } 80 \% \text { sesuai dengan beberapa jenis } \\
\text { Capnodiales lain termasuk Teratosphaeria considenianae CPC } 13032 \\
\text { no akses GQ852791 dan Colletogloeopsis considenianae CBS } 120087 \\
\text { no akses DQ923527 }\end{array}$ & Capnodiales \\
\hline Plenty 314 & $\begin{array}{l}98 \% \text { sesuai dengan beberapa jenis Catenulostroma termasuk } \\
\text { C. protearum strain CPC } 15369 \text { no akses pada NCBI GU214629 dan } \\
\text { C. hermanusense strain CBS } 128768 \text { no akses JF499833 }\end{array}$ & Capnodiales \\
\hline
\end{tabular}

3. Analisis filogenetik

\section{Analisis filogenetik (Gambar 2)}

dilakukan terhadap semua sampel jamur

yang teramplifikasi dari daun jarum $P$.

radiata. Sekuen dari database yang memiliki

kemiripan dengan sekuen sampel yang dianalisis juga dimasukkan dalam analisis. Sekuen Mycosphaerella pini (sinonim dengan Dothisthroma pini) yang didapat dari database NCBI yang merupakan salah satu jenis jamur penyebab penyakit pada $P$. radiata juga disertakan sebagai outgroup. 


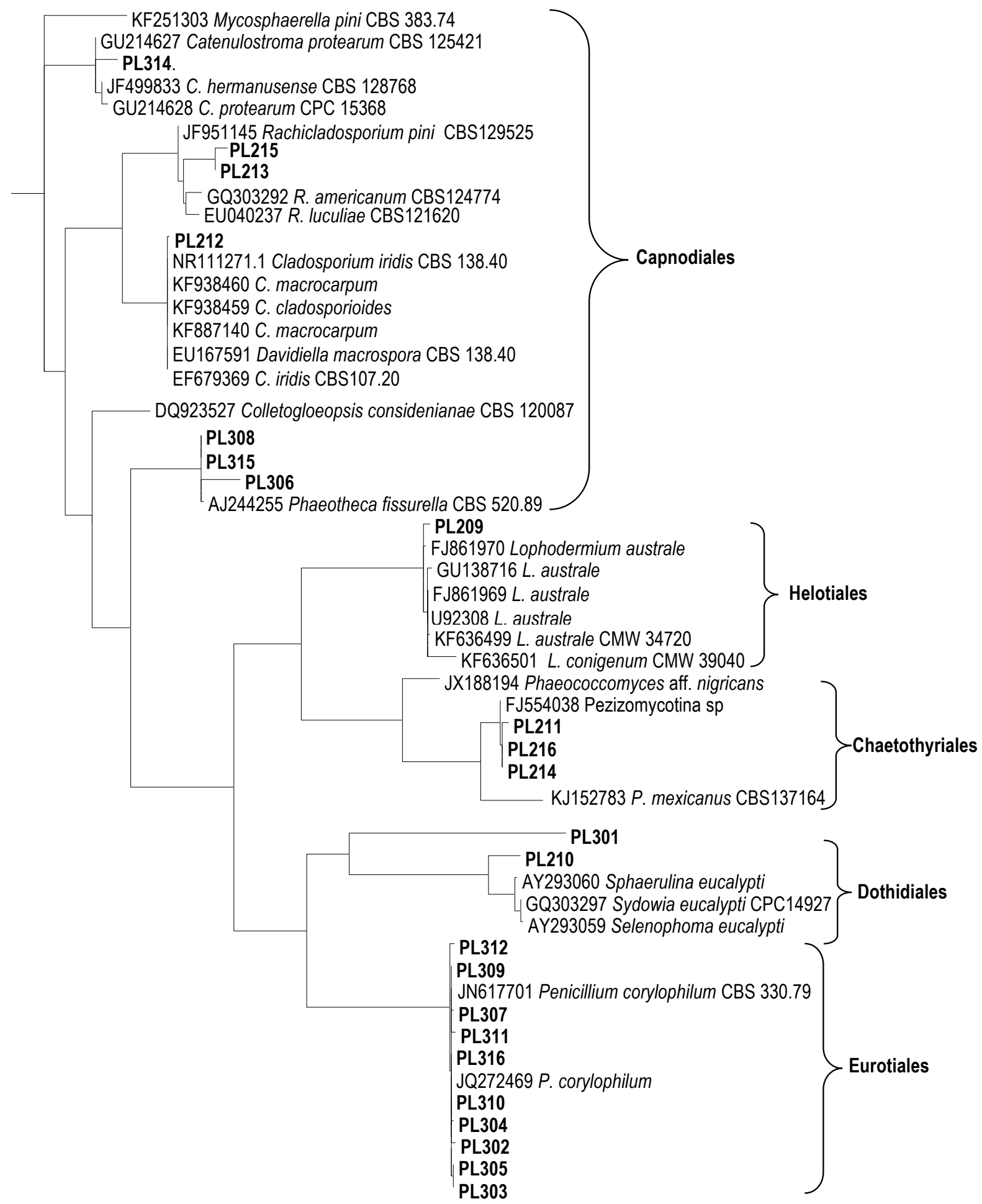

Gambar 2. Analisis filogenetik menggunakan pendekatan maximum likelihood terhadap semua sekuen ITS dari sampel DNA jamur (PL= Plenty) yang teramplifikasi dari daun Pinus radiata. Sekuense dari jamur Mycosphaerella pini digunakan sebagai outgroup dalam analisis ini 
Analisis filogenetik memberikan gambaran lebih jelas mengenai kedudukan semua sampel DNA jamur terhadap sampel lainnya dan juga terhadap sekuense yang diperoleh dari database. Sebagian besar sekuen database yang digunakan dalam penelitian ini merupakan sekuense dari isolat jamur yang sudah diketahui identitasnya menggunakan karakter morfologi dan kultur atau herbarium sampelnya telah disimpan di pusat database di CBS (The Centralbureau voor Schimmelcultures Fungal Biodiversity Centre).

\section{B. Pembahasan}

Penelitian tentang jamur endofit yang hidup pada berbagai jenis konifer telah banyak dilakukan, namun umumnya jamur tersebut diisolasi terlebih dahulu dan ditumbuhkan pada media agar (Romeralo et al; 2012, Yoo and Eom, 2012; Qadri et al., 2014). DNA jamur yang hidup pada daun jarum $P$. radiata dapat diekstraksi dan diidentifikasi secara langsung dari daun jarum menggunakan metode sederhana dengan buffer SDS yang dapat dipakai untuk mengekstraksi DNA jamur dari badan buah dan isolat atau kultur jamur (Sulistyawati, 2004). Daun jarum yang telah dilayukan memberikan hasil amplifikasi yang lebih jelas dibandingkan daun yang masih segar. Sebelum penelitian ini dilaksanakan, ekstraksi DNA menggunakan sampel berupa daun segar telah dilakukan dengan beberapa metode ekstrasi termasuk menggunakan DNA extraction Kit yang beredar di pasaran, namun tidak didapatkan hasil yang konsisten jika melibatkan sampel dalam yang besar (data tidak dipublikasi). Penggunaan daun yang telah dilayukan atau dikeringanginkan juga memberikan kelebihan yaitu kemudahan dalam proses penyimpanan sampel, karena setelah daun layu dapat disimpan di dalam amplop kertas pada suhu ruangan (untuk penyimpanan jangka pendek) atau disimpan dalam kantong plastik pada lemari beku suhu $-40^{\circ} \mathrm{C}$ (untuk penyimpanan jangka panjang). Jenis jamur yang teridentifikasi pada penelitian ini merupakan anggota dari berbagai familia seperti Eurotiales (ordo Eurotiomycetes), Capnodiales (ordo Dothideomycetes), Helotiales (ordo Leotiomycetes), Pleosporales (ordo Dothideomycetes), dan Chaetothyriales (ordo Chaetothyriomycetes). Penicillium corylophilum merupakan jenis jamur yang paling banyak teridentifikasi (10 sampel) pada penelitian ini. Jenis jamur ini ditemukan sebagai endofit pada beberapa jenis tanaman 
antara lain Withania somnifera (Khan et al., 2010) serta beberapa jenis tanaman obat seperti Launea spinosa dan Teucrium polium (Selim et al., 2011). Pada hutan Pinus, jamur ini ditemukan sebagai saprofit pada sampel tanah (Grantina-Ievina et al., 2013), serta pada serasah daun (Osono et al., 2006). Sebagai endofit jenis tersebut ditemukan pada batang Pinus ponderosa (Kurth et al., 2013). Beberapa jenis Penicillium lain juga ditemukan sebagai jamur endofit pada batang Pinus wallichiana (Qadri et al., 2014),

Capnodiales memiliki jenis paling banyak yang ditemukan pada studi ini, meliputi jenis Catenulostroma sp., Cladosporium sp, Phaeotheca fissurella dan Rachicladosporium sp. Beberapa penelitian pada jenis Pinus yang berbeda juga menemukan jenis-jenis jamur tersebut sebagai endofit pada daun jarum (Ganley, 2004; Arnold, 2007; Qadri et al., 2014). Dothidiomycetes tercatat sebagai ordo yang memiliki jumlah jenis terbanyak serta frekuensi yang paling besar pada daun jarum (Botella and Diez, 2011; Qadri et al., 2014). Sordariomycetes merupakan ordo yang umumnya menempati urutan kedua setelah Dothiomycetes, namun dalam penelitian ini anggota dari kelompok ini tidak satupun teridentifikasi. Dalam penelitian yang dilakukan oleh Arnold et al. (2007) juga tidak berhasil mengidentifikasi jenis Sordariomycetes melalui teknik identifikasi DNA jamur secara langsung dari sampel daun, meskipun ditemukan dalam jumlah jenis yang besar pada penggunaan teknik isolasi. Hal ini mungkin disebabkan karena jenis Sordariomycetes memiliki biomassa yang kecil didalam sampel daun namun memiliki pertumbuhan yang cepat sehingga mudah teridentifikasi melalui teknik isolasi jamur dengan menumbuhkan miselium pada media agar.

Pada penelitian ini jenis jamur patogen yang umumnya ditemukan pada P. radiata di belahan bumi bagian selatan seperti Dothisthroma pini (Bradshaw, 2004), Lophodermium pinastri (Choi and Simpson, 1991) maupun Cyclaneusma minus (Bulman et al., 2008) tidak terdeteksi. Hal ini mungkin disebabkan karena sampel daun yang digunakan adalah sampel daun yang masih berwarna hijau dan terlihat sehat serta diambil dari pohon $P$. radiata yang masih muda (berumur 4 tahun), sedangkan jamur patogen umumnya muncul setelah tanaman $P$. radiata berumur lebih dari 8 tahun (Bulman et al., 2008). 


\section{KESIMPULAN}

Hasil penelitian menunjukkan bahwa:

1. DNA jamur dapat diekstraksi secara langsung dari daun jarum Pinus radiata.

2. Daun jarum $P$. radiata yang sudah dikeringkan / dilayukan akan memberikan hasil amplifikasi DNA yang lebih jelas daripada daun yang masih segar / basah.

3. Pengeringan pada suhu ruangan memberikan hasil amplifikasi DNA yang lebih jelas dibandingkan pengeringan metode lainnya.

4. Jamur yang tumbuh pada daun jarum $P$. radiata yang teridentifikasi pada penelitian ini adalah dari kelompok Eurotiales, Capnodiales, Helotiales, Pleosporales, dan Chaetothyriales.

5. Capnodiales memiliki jumlah jenis yang paling banyak ditemukan, pada penelitian ini

6. Tidak ditemukan jenis jamur patogen pada penelitian ini.

\section{UCAPAN TERIMAKASIH}

Penelitian ini merupakan bagian dari penelitian besar yang dibiayai oleh Australian Research council, Forestry Tasmania, Taswood Growers, Norske Skog, Forest NSW and Hosking Ltd. New Zealand. Penulis mengucapkan terimakasih kepada Anna Smith yang telah membantu dalam pengambilan sampel di lapangan dan kepada Morag Glen yang telah memberikan bimbingan teknis di laboratorium serta dalam analisa data.

\section{DAFTAR PUSTAKA}

ABARES 2012. Agricultural commodity statistics 2012. Canberra: Australian Bureau of Agricultural and Resource Economics and Sciences.

Altschul, S., Madden, T., Schaffer, A., Zhang, J., Zheng, Z., Miller, W. \& Lipman, D. 1997. Gapped BLAST and PSI-BLAST: a new generation of protein database search programs. Nucleic Acids Res., 25, 33893402.

Arnold, A. E. 2007. Understanding the diversity of foliar endophytic fungi: progress, challenges, and frontiers. Fungal Biology Reviews, 21, 51-66.

Arnold, A. E., Henk, D. A., Eells, R. L., Lutzoni, F. \& Vilgalys, R. 2007. Diversity and phylogenetic affinities of foliar fungal endophytes in loblolly pine inferred by culturing and environmental PCR. Mycologia, 99, 185-206.

Botella, L. \& Diez, J. J. 2011. Phylogenic diversity of fungal endophytes in Spanish stands of Pinus halepensis. Fungal Diversity, 47, 9-18.

Bradshaw, R. E. 2004. Dothistroma (red-band) needle blight of pines and the dothistromin toxin: a review. Forest Pathology, 34, 163-185.

Bulman, L. S., Ganley, R. J. \& Dick, M. 2008. Needle diseases of radiata pine in New Zealand. 
Client Report. Rotorua: SCION.

Choi, D. \& Simpson, J. A. 1991. Needle cast of Pinus radiata in New South Wales. Australian Journal of Botany, 39, 137-152.

Collett, N. G. \& Elms, S. 2009. The control of sirex wood wasp using biological control agents in Victoria Australia. Agricultural and Forest Entomology, 11, 283-294.

Felsenstein, J. 1989. PHYLIP - Phylogeny Inference Package (Version 3.2). Cladistics, 5, 164166.

Ganley, R. J., Brunsfeld, S.J. and Newcombe, G. 2004. A community of unknown, endophytic fungi in western white pine. Proceeding of the National Academy of Science of the United States of America, 101, 7-12.

Ganley, R. J., Watt, M. S., Kriticos, D. J., Hopkins, A. J. M. \& Manning, L. K. 2011. Increased risk of pitch canker to Australasia under climate change. Australasian Plant Pathology, 40, 228-237.

Glen, M., I. C. Tommerup, N. L. Bougher, and P.A. O’ Brien 2002. Are Sebacinaceae common and widespread ectomycorrhizal associates of Eucalyptus species in Australian forests? Mycorrhiza, 12, 243-247.

Grantina-Ievina, L., Kasparinskis, R., Tabors, G. \& Nikolajeva, V. 2013. Features of saprophytic soil microorganism communities in conifer stands with or without Heterobasidion annosum sensu lato infection: a special emphasis on Penicillium spp. . Environmental and Experimental Biology, 11, 23-38.

Khan, R., Shahzad, S., Iqbal choudhary, M., Khan, S. A. \& Ahmad, A. 2010. Communities of endophytic fungi in medicinal plant Withania somnifera. Pakistan Journal of Botany, 42, 1281-1287.

Kurth, V. J., Fransioli, N., Fule, P. Z., Hart, S. C. \& Gehring, C. A. 2013. Stand-replacing wildfires alter the community structure of wood-inhabiting fungi in southwestern ponderosa pine forests of the USA. Fungal Ecology, 6, 192-204.

Larena, I., Salazar, O., Gonzales, V., Julian, M. C. \& Rubio, V. 1999. Design of a primer for ribosomal DNA internal transcribed spacer with enhanced specificity for ascomycetes. Journal of Biotechnology, 75, 187-194.

May, B. M. 2004. Assessment of the causality of Essigella-ascribed defoliation of midrotation radiata pine and its national impact in terms of cost of lost wood production. In: Project, R. (ed.) PN04-4002. Melbourne, Australia: Forest and Wood Products Research and Development Corporation.

Mead, D. J. 2013. Sustainable management of Pinus radiata plantations. FAO Forestry Paper. Rome: FAO.

Moricca, S. \& Ragazzi, A. 2007. Fungal endophytes in Mediterranean oak forest: a lesson from Discula quercina Phytopathology, 98.

NZFOA 2012. New Zealand Forest Industry Facts and Figures 2011/2012. In: Association, N. Z. F. O. (ed.). Wellington.

Osono, T., Hirose, D. \& Fujimaki, R. 2006. Fungal colonization as affected by litter depth and decomposition stage of needle litter. Soil Biology and Biochemistry, 38, 2743-2752.

Page, R. D. M. 1996. TREEVIEW: An application to display phylogenetic trees on personal computers. Computer Applications in the Biosciences, 12, 357-358.

Podger, F. D. \& Wardlaw, T. J. 1990. Spring needle cast of Pinus radiata in Tasmania. I. Symptoms, distribution and association with Cyclaneusma minus. New Zealand Journal of Forestry Science, 20, 184-205.

Qadri, M., Rajput, R., Abdin, M. Z., Vishwakarma, R. A. \& Riyaz-Ul-Hassan, S. 2014. Diversity, molecular phylogeny, and bioactive potential of fungal endophytes associated with the Himalayan blue pine (Pinus wallichiana). Microbial Ecology, 67, 877-887.

Raeder, U. \& Broda, P. 1985. Rapid preparation of DNA from filamentous fungi. Letters in Applied Microbiology, 1, 17-20

Ramsfield, T. D., Power, M. W. P. \& Kimberley, M. O. 2013. The relationship between pruning and the incidence of Neonectria fuckeliana in Pinus radiata. New Zealand Journal of Forestry Science, 43, 1-6.

Romeralo, C., Diez, J. J. \& Santiago, N. F. 2012. Presence of fungi in Scots pine needles found to correlate with air quality as measured by bioindicators in northern Spain. Forest Pathology, 42, 443-453.

Selim, K., El-Beih, A., AbdEl-Rahman, T. \& El-Diwany, A. 2011. Biodiversity and antimicrobial activity of endophytes associated with Egyptian medicinal plants. Mycosphere, 2, 669-678.

Sulistyawati, P. 2004. Identifikasi jenis jamur dengan teknik molekuler. Jurnal Penelitian Tanaman Hutan, 1, 2.

Tamura, K., Dudley, J., Nei, M. \& Kumar, S. 2007. MEGA4: Molecular Evolutionary Genetics Analysis (MEGA) software version 4.0. Molecular Biology Evolution, 24, 15961599.

Thompson, J. D., Higgins, D. G. \& Gibson, T. J. 1994. Clustal W: improving the sensitivity of progressive multiple sequence alignment through sequence weighting, positionspecific gap penalties and weight matrix 
choice. Nuc.Acid. Res., 22 4673-4680.

USDAFS 1993. Pest risk assessment of the importation of Pinus radiata, Nothofagus dombeyi, and Laurelia philippiana logs from Chile. Miscellaneous Publication Washington, D. C United States Department of Agriculture, Forest Service.

Watson, M. C., Kriticos, D. J., Drayton, G. M., Teulon, D. A. J. \& Brockerhoff, E. G. 2008. Assessing the effect of Essigella californica on Pinus radiata at two sites in New Zealand. New Zealand Plant Protection, 61, 177-184.
Watt, M., Rolando, C., Palmer, D. \& Bulman, L. 2011. Predicting the severity of Cyclaneusma minus on Pinus radiata in New Zealand. Forest Health News. Rotorua: SCION.

White, T. J., Bruns, T., Lee, S. \& Taylor, J. 1990. Amplification and direct sequencing of fungal ribosomal RNA genes for phylogenetics, Academic Press, Inc.

Yoo, J. J. \& Eom, A. H. 2012. Molecular identification of endophytic fungi isolated from needle leaves of conifers in Bohyeon Mountain, Korea. Mycobiology, 40, 231-235. 